\title{
EXPERIMENTAL INVESTIGATION OF HEAT TRANSFER THROUGH WINDOWS WITH INTERIOR BLINDS
}

\author{
Vijay Kumar ${ }^{1}$, Anuranjan Sharda ${ }^{2}$ \\ ${ }^{1}$ Research Scholar, Department of Mechanical Engineering, Rayat Bahra Institute of Engineering And Bio-Technology, \\ Kharar, Mohali (PB), India, vkparyal@yahoo.com \\ ${ }^{2}$ Associate Prof., Department of Mechanical Engineering, Rayat Bahra Institute of Engineering And Bio-Technology, \\ Kharar, Mohali (PB), India
}

\begin{abstract}
Windows are designed primarily to control the indoor climate and also to provide proper ventilation (air circulation). The primary objective is achieved by controlling the heat flow through the window from inside to outside in winter \& from outside to inside in summer. Window solar gain has a strong influence on the building energy consumption and peak cooling load. Double glazed window are known to prevent the entry of solar gain to inside the room. Shading systems such as Venetian blinds, louver shades, draperies etc. enhances the control of solar gain through windows. In this paper the thermal performance of a double-glazed window with adjacent commercially available blinds has been studied using LBNL research software WINDOWS 6.3 and the results so obtained are validated using a Guarded Heat Plate Apparatus. Though this type of glazing system has already been studied for colder climatic conditions in the west, due to the unavailability of literature on local climatic conditions its use in tropical countries like India is limited. A parametric study for climatic conditions of an Indian city, Chandigarh has been made to give an insight to the thermal performance of glazing systems with interior blinds. In this study the effect of different parameters such as types of glazing systems (single and double glazed), pane to blind spacing $(20 \mathrm{~mm}, 30 \mathrm{~mm}$ and $40 \mathrm{~mm})$, the Slat angle $\left(0^{\circ}\right.$ and $\left.90^{\circ}\right)$ and the climatic conditions of Chandigarh (Hot and Dry, Hot and Humid, Cold and Dry) on the Thermal transmittance (U-value) is studied.
\end{abstract}

Index Terms: Heat Transfer, Glazing, U-value, R-value

\section{INTRODUCTION}

Solar gain is divided into three parts as it passes through a glazing material. Some is transmitted, some is reflected, and the left over is absorbed as shown in Fig. 1. These three components decide many of the other energy performance characteristics of a glazing system, such as the solar heat gain coefficient and thermal transmittance or U-value $\left(\mathrm{W} / \mathrm{m}^{2} \mathrm{k}\right)$. The inverse of heat flow, or resistance to heat transfer, is expressed as Thermal Resistance or simply R-value.

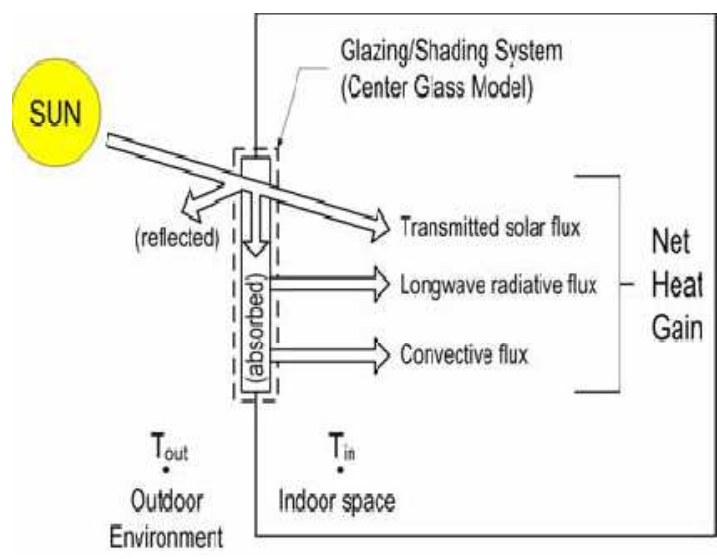

Fig- 1: Net heat gain into the indoor space and its components. [1]

In developing countries like India, drapes are generally used as shading system where as in the western countries venetians are used. These drapes are used without proper investigation of their UValue, SHGC (Solar Heat Gain Coefficient). 
Venetian blinds are used along with the windows to control sun-light and heat transfer up-to some extent. The presence of these shading will affect natural convection and radiant heat transfer from the window, due to which there will be a change in the heat transmission and solar heat gain, through window. Solar radiation absorbed by glazing layers will contribute to the temperature driven heat transfer, while solar radiation transmitted by the glazing system will be independent of the temperature driven heat transfer. Absorbed solar radiation will be partially transmitted into the conditioned space and will be included in SHGC. Heat flows from warmer to cooler bodies, thus from inside to outside in winter, and reverses direction in summer during periods when the outside temperature is greater than indoors.

Venetian blind has horizontal or vertical slats, one above another. These blinds are generally made of metal or plastic; wooden slats usually referred to as wood blinds or bamboo blinds. These slats can be rotated such that they overlap with one side facing inward and then in the opposite direction such that they overlap with the other side facing inward. Between these two extremes, various degrees of angles may be affected, by the use of lift cords passing through slots in each slat.

Many studies have been conducted for these types of blinds in colder countries [2][3] however their use in tropical countries like India is still limited. And even if these are used no weightage to thermal performance is given; only the aesthetic appeal is taken care of. This is due to the non-availability of research in this area. The authors are of the view that a greater understanding of thermal performance of such system in Indian climate will give a greater impetus to their usage in tropical countries.

India is divided into six climatic zones [4]. All northern states including Chandigarh fall in composite climate zone. Composite climate is further divided into three categories i.e Hot-Dry, Hot-Humid and Cold-Dry.

The configuration selected for the present study consists of a double-glazed window with interior venetian blinds in Indian climate as shown in figure 2.

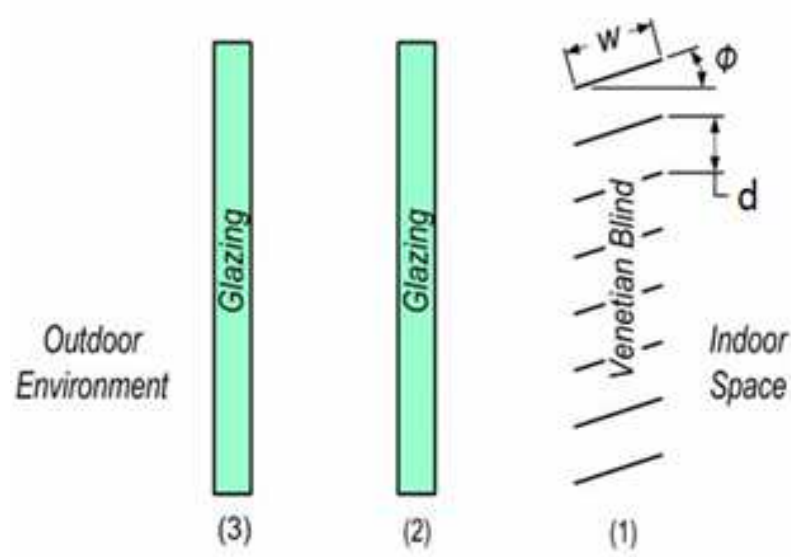

Fig- 2: System layout: double-glazed window with Indoor side venetian blind and blind dimensions. [1]

Where $\mathrm{w}=$ width of blind,

$\phi=$ slat Angle,

$\mathrm{d}=$ distance between consecutive blinds

\section{SOFTWARE AND SIMULATION}

\subsection{Software}

For simulating the heat transfer through doubleglazed windows with interior venetian blinds, Window 6.3 software is used, which is publicly available LBNL WINDOW IBM PC compatible computer program, developed by the building technologies group at the Lawrence Berkeley Laboratory [5]. This software is useful in calculating the thermal and optical properties necessary for heat transfer analyses of fenestration products. New products with measured thermal and optical properties can also be added to the software database. WINDOW 6.3 is the latest in a series of programs released by the Lawrence Berkeley Laboratory. Major parametric changes can be made in this software while modelling geometrical models of different glazing systems. The parameters which can be changed includes spacing between different layers, types of blinds, slat angles, type of glazing, environmental conditions, fluid in between the panes and so many more. Thus using different input parameters, results of various output parameters such as SHGC, U-value, $\mathrm{K}_{\text {eff, }}$ (Effective thermal conductivity) etc. can be determined. All the 
calculations procedures for determining various responses are available at LBNL website [6].

\subsection{Simulation}

The simulated study is designed on the basis of one factor approach to include the effect of control factors on response factor. The glass panes of size $635 \times 635 \times 3 \mathrm{~mm}$ are selected for conducting simulation-runs for various glazing systems. The slat angle is adjustable. Various levels of different input simulation factors are shown in table 1 .

Table-1: Control parameters

\begin{tabular}{|l|l|l|l|l|}
\hline \multirow{2}{*}{ Levels } & \multicolumn{3}{|l|}{ Control Parameters } \\
\cline { 2 - 5 } & $\begin{array}{l}\text { Glazing } \\
\text { Type }\end{array}$ & $\begin{array}{l}\text { Pane- } \\
\text { Blind } \\
\text { Spacing } \\
(\mathrm{mm})\end{array}$ & $\begin{array}{l}\text { Slat } \\
\text { Angle } \\
\left({ }^{\circ} \mathrm{C}\right)\end{array}$ & Climate \\
\hline 1 & Single & 20 & 0 & $\begin{array}{l}\text { Hot- } \\
\text { Dry }\end{array}$ \\
\hline 2 & Double & 30 & 90 & $\begin{array}{l}\text { Hot- } \\
\text { Humid }\end{array}$ \\
\hline 3 & & 40 & $\begin{array}{l}\text { Cold- } \\
\text { Dry }\end{array}$ \\
\hline
\end{tabular}

The single response parameter U-value is considered. The full factorial approach consists of a design of total 36 experiments. The design along the response is shown in table 2.
Table-2: Full factorial design for evaluating U-value

\begin{tabular}{|c|c|c|c|c|c|c|}
\hline $\begin{array}{l}\text { S.N } \\
\text { o }\end{array}$ & $\begin{array}{l}\text { Glazin } \\
\text { g Type }\end{array}$ & $\begin{array}{l}\text { Spacin } \\
\mathrm{g}(\mathrm{mm})\end{array}$ & $\begin{array}{c}\text { Slat } \\
\text { Angl } \\
\text { e } \\
\left({ }^{\circ}\right)\end{array}$ & $\begin{array}{l}\text { Climat } \\
\mathrm{e}\end{array}$ & $\begin{array}{l}\text { Exp. } \\
\text { U- } \\
\text { Valu } \\
\text { e }\end{array}$ & $\begin{array}{c}\text { Sim. } \\
\text { U- } \\
\text { Valu } \\
\text { e }\end{array}$ \\
\hline 1 & Single & 20 & 0 & H-D & 4.18 & 5.12 \\
\hline 2 & Single & 30 & 0 & H-D & 3.56 & 4.33 \\
\hline 3 & Single & 40 & 0 & H-D & 4.23 & 5.15 \\
\hline 4 & Single & 20 & 90 & H-D & 3.58 & 4.34 \\
\hline 5 & Single & 30 & 90 & H-D & 4.21 & 5.14 \\
\hline 6 & Single & 40 & 90 & H-D & 3.57 & 4.37 \\
\hline 7 & Double & 20 & 0 & H-D & 2.23 & 2.72 \\
\hline 8 & Double & 30 & 0 & H-D & 2.1 & 2.48 \\
\hline 9 & Double & 40 & 0 & H-D & 2.26 & 2.73 \\
\hline 10 & Double & 20 & 90 & H-D & 2.07 & 2.46 \\
\hline 11 & Double & 30 & 90 & H-D & 2.28 & 2.74 \\
\hline 12 & Double & 40 & 90 & H-D & 2.09 & 2.74 \\
\hline 13 & Single & 20 & 0 & H-H & 3.72 & 4.54 \\
\hline 14 & Single & 30 & 0 & H-H & 3.17 & 3.87 \\
\hline 15 & Single & 40 & 0 & H-H & 3.74 & 4.56 \\
\hline 16 & Single & 20 & 90 & H-H & 1.86 & 2.24 \\
\hline 17 & Single & 30 & 90 & H-H & 3.76 & 4.58 \\
\hline 18 & Single & 40 & 90 & H-H & 3.1 & 3.79 \\
\hline 19 & Double & 20 & 0 & $\mathrm{H}-\mathrm{H}$ & 2.13 & 2.52 \\
\hline 20 & Double & 30 & 0 & H-H & 1.87 & 2.29 \\
\hline 21 & Double & 40 & 0 & $\mathrm{H}-\mathrm{H}$ & 2.13 & 2.52 \\
\hline 22 & Double & 20 & 90 & H-H & 1.85 & 2.24 \\
\hline 23 & Double & 30 & 90 & $\mathrm{H}-\mathrm{H}$ & 2.14 & 2.52 \\
\hline 24 & Double & 40 & 90 & H-H & 1.84 & 2.24 \\
\hline
\end{tabular}


pISSN: 2321-7308

\begin{tabular}{|c|c|c|c|c|c|c|}
\hline 25 & Single & 20 & 0 & C-D & 3.85 & 4.7 \\
\hline 26 & Single & 30 & 0 & C-D & 3.25 & 4.01 \\
\hline 27 & Single & 40 & 0 & C-D & 3.87 & 4.72 \\
\hline 28 & Single & 20 & 90 & C-D & 3.31 & 4.06 \\
\hline 29 & Single & 30 & 90 & C-D & 3.86 & 4.7 \\
\hline 30 & Single & 40 & 90 & C-D & 3.33 & 4.07 \\
\hline 31 & Double & 20 & 0 & C-D & 1.98 & 2.41 \\
\hline 32 & Double & 30 & 0 & C-D & 1.83 & 2.19 \\
\hline 33 & Double & 40 & 0 & C-D & 1.99 & 2.41 \\
\hline 34 & Double & 20 & 90 & C-D & 1.7 & 2.18 \\
\hline 35 & Double & 30 & 90 & C-D & 1.92 & 2.41 \\
\hline 36 & Double & 40 & 90 & C-D & 1.8 & 2.19 \\
\hline
\end{tabular}

The geometrical properties of the venetian blind are shown in the table 4.

Table-4: Geometrical properties of Venetian Blind

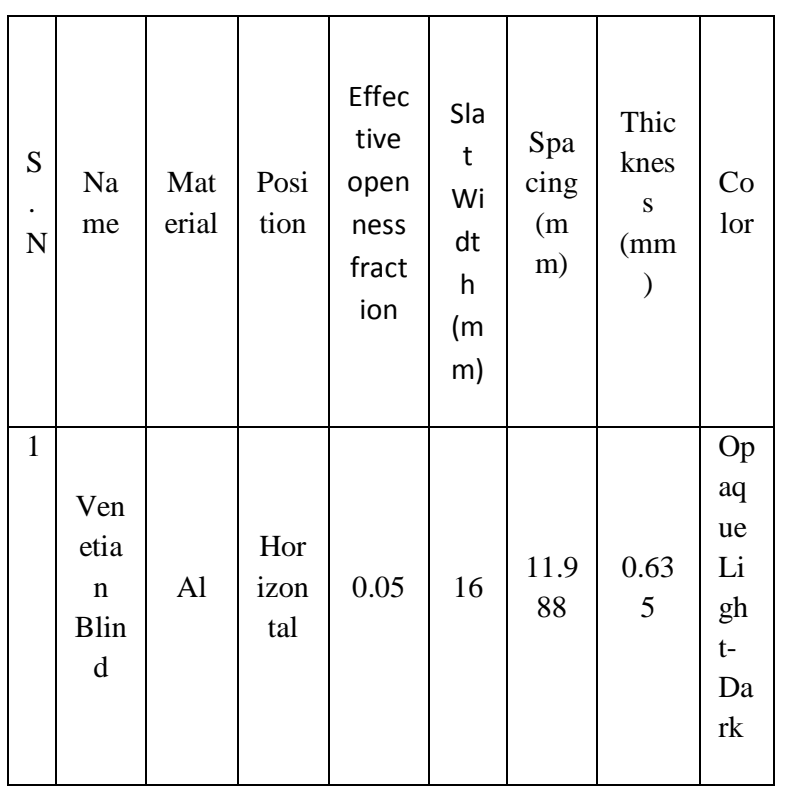
configuration along with the input parameters having values corresponding to composite-climatic zone of India is used. Averaged Wind-speed and solar radiation are obtained from the internet [7] to feed inputs to the software. The inner room temperature is kept at the design conditions according to Indian climate [8]. For convectional heat transfer, ASHRAE/NFRC model and Windward Directional model are selected through the software. Both the effective sky emissivity and the effective room emissivity are assumed to be equal to 1 .

The properties of the air at standard temperature and pressure is shown in the table 3 .

Table-3: Properties of air at standard temperature and pressure

\begin{tabular}{|l|l|l|l|l|}
\hline $\begin{array}{l}\text { Conduction } \\
\text { Coefficient }\end{array}$ & $\begin{array}{l}\text { Viscosity } \\
\text { Coefficient }\end{array}$ & $\begin{array}{l}\text { Specific } \\
\text { Heat } \\
\text { Coefficient }\end{array}$ & Density & $\begin{array}{l}\text { Prand } \\
\text { tl }\end{array}$ \\
\hline $\mathrm{KW} / \mathrm{m} \mathrm{k}$ & $\mathrm{Ns} / \mathrm{m}^{2}$ & $\mathrm{KJ} / \mathrm{kg} \mathrm{C}$ & $\mathrm{kg} / \mathrm{m}^{3}$ & \\
\hline 0.0002405 & 0.0001785 & 1.0175 & 1.38848 & $\begin{array}{l}0.719 \\
7\end{array}$ \\
\hline
\end{tabular}

The solar and optical properties of venetian blind and glass are shown in table 5.

Table-5: Solar and optical properties of Venetian blind and glass

\begin{tabular}{|c|c|c|c|}
\hline \multicolumn{2}{|c|}{ Description } & $\begin{array}{l}\text { Venetian } \\
\text { Blind }\end{array}$ & Glass \\
\hline \multirow{4}{*}{ Solar } & $\begin{array}{l}\text { Trans, Front } \\
\left(T_{\text {sol }}\right)\end{array}$ & 0 & 0.83 \\
\hline & $\begin{array}{l}\text { Trans, Back } \\
\left(\mathrm{T}_{\mathrm{sol}}{ }^{2}\right)\end{array}$ & 0 & 0.83 \\
\hline & $\begin{array}{l}\text { Reflection } \\
\text { Front }\left(\mathrm{R}_{\text {sol }}\right)\end{array}$ & 0.7 & 0.08 \\
\hline & $\begin{array}{l}\text { Reflection } \\
\text { Back }\left(\mathrm{R}_{\text {sol }}{ }^{2}\right)\end{array}$ & 0.4 & 0.08 \\
\hline \multirow{4}{*}{ Visible } & $\begin{array}{l}\text { Trans, Front } \\
\left(\mathrm{T}_{\mathrm{vis}}\right)\end{array}$ & 0 & 0.9 \\
\hline & $\begin{array}{l}\text { Trans, Back } \\
\left(\mathrm{T}_{\mathrm{vis}}{ }^{2}\right)\end{array}$ & 0 & 0.9 \\
\hline & $\begin{array}{l}\text { Reflection } \\
\text { Front }\left(\mathrm{R}_{\mathrm{vis}}\right) \\
\end{array}$ & 0.7 & 0.08 \\
\hline & $\begin{array}{l}\text { Reflection } \\
\text { Back }\left(\mathrm{R}_{\mathrm{vis}}\right)\end{array}$ & 0.4 & 0.08 \\
\hline \multirow{2}{*}{ IR } & $\begin{array}{l}\text { Emis, Front } \\
\text { (Emis1) }\end{array}$ & 0.9 & 0.84 \\
\hline & $\begin{array}{l}\text { Emis, Back } \\
\text { (Emis2) }\end{array}$ & 0.9 & 0.84 \\
\hline
\end{tabular}


The peak temperature conditions for each of these climates [8] are shown in table 6.

Table-6: Composite climate conditions

\begin{tabular}{|l|l|l|l|l|}
\hline \multirow{2}{*}{} & \multicolumn{4}{|l|}{ Composite Climate Condition } \\
\cline { 2 - 5 } & & & & \\
$\begin{array}{l}\text { Climate } \\
\text { Condition }\end{array}$ & $\mathrm{T}_{\text {out }}\left({ }^{\circ} \mathrm{C}\right)$ & $\begin{array}{l}\mathrm{T}_{\text {in }} \\
\left({ }^{\circ} \mathrm{C}\right)\end{array}$ & $\begin{array}{l}\text { Solar } \\
\text { Radiation } \\
\mathrm{W} / \mathrm{m}^{2}\end{array}$ & $\begin{array}{l}\text { Wind } \\
\text { Speed } \mathrm{m} / \mathrm{s}\end{array}$ \\
\hline Hot-Dry & 43 & 25 & 6570 & 4.815 \\
\hline Hot-Humid & 34 & 25 & 5470 & 4.02 \\
\hline Cool-Dry & 5 & 25 & 3948 & 3.95 \\
\hline
\end{tabular}

\section{EXPERIMENTAL SET UP}

The experimental set-up is shown in Fig.3.The apparatus similar to that used by Wright and Sullivan [9] consists of primarily two copper plates i.e hot copper plate, cold copper plate, water bath, copper tubes, temperature indicators of the bath, rota-meter, heaters i.e main and guard heaters, glazing system, venetian blinds, power supply system and other accessories. The size of two copper plates (hot plate and cold plate) is $635 \times 635 \times 12.5 \mathrm{~mm}$ each. The plates are placed in such a position so that they keep facing each other and can be maintained at constant temperatures. Both plates are held at desired constant temperature by a circulating a steady flow mixture of water and glycol through a manifold of tubes attached at the back of the copper plates. The warm copper plate contains three guarded heater plates. These heater plates lie in vertical position at equal distance. The heat transfer that takes place over the face of each of the guarded heater can be measured. The adjustment of the electrical power supplied to the heater plate is made until zero temperature difference is achieved between the heater plate and the warm copper plate. At this position, there will be no heat transfer between the heater and the warm copper plate and all the electrical energy supplied is transferred across the gap to the cold copper plate.

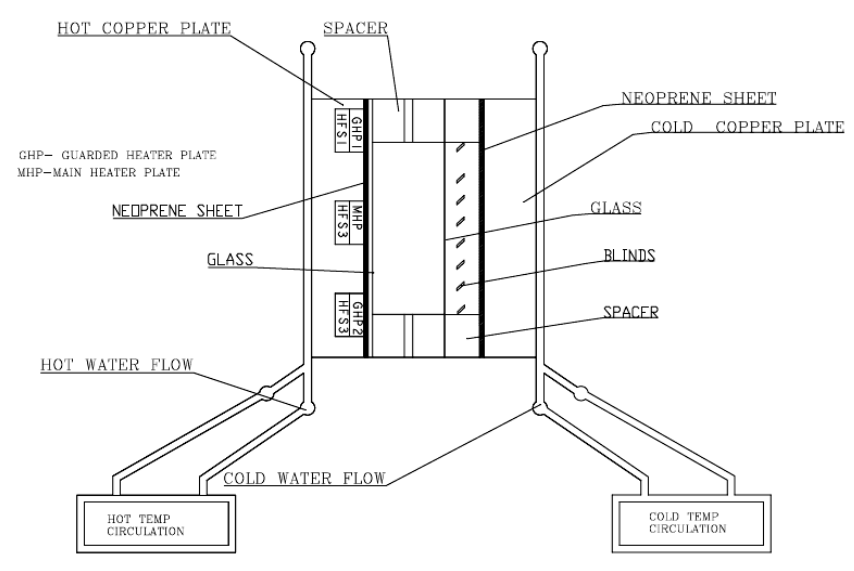

Fig-3: Schematic of experiment set up

The temperature difference is sensed by a heat flux meter that is sandwiched between these two plates. The glazing system to be tested is placed at desirable position in between the plates. In order to prevent the direct contact between the glazing system and the copper plates, $3 \mathrm{~mm}$ thick sheet of neoprene is placed between them. After the glazing system and the blinds are securely positioned in the desired place, the outside of the plates and glazing system assembly is completely covered with insulation in order to prevent thermal losses. Then the constant temperature baths which feed the two copper plates can be started.

\subsection{Methodology}

The outer pane and inner pane temperature difference from simulated study is considered for temperature difference of hot and cold plate in the guarded hot plate apparatus. The sample is sandwiched between the hot and cold plates to determine its $\mathrm{C}$-value. The measuring methodology [9] used is discussed below: For measuring the heat flux from the exposed surface of a GHP, the rate of electrical energy supplied to the heater plate $\mathrm{Q}$, is determined by measuring the heater wire voltage $\mathrm{V}$ and current $\mathrm{I}$, directly by using a digital volt meter and an ammeter.

$Q=I * V$ (i)

The heat flux from the face of heater plate, $S$ is then calculated by using heat flux meter output voltage, HFMV as:

$\mathrm{S}=(\mathrm{Q}-\alpha$. HFMV) $/$ Ahp

Where $\alpha=$ heat flux meter calibration constant $\mathrm{A}_{\mathrm{hp}}=$ Face area of the heater plate 
After the heat flux, has been measured; the glass to glass U-value of the glazing system, C (thermal resistance) can be measured as:

$\mathrm{C}=((\Delta \mathrm{T} / \mathrm{S})-2 \mathrm{Rn})^{-1}$

Where $\Delta \mathrm{T}=$ temperature difference between the warm and cold copper plate

And

$\mathrm{Rn}=$ thermal resistance of neoprene sheet $=0.017 \mathrm{~m}^{2}$ $\mathrm{C} / \mathrm{W}$

The U- Value based on measurements can finally be find out as:

$\mathrm{U}=\left(\mathrm{C}^{-1}+\mathrm{h}_{1}^{-1}+\mathrm{h}_{2}^{-1}\right)^{-1}$

Where $h_{1}=$ indoor heat transfer coefficient $\mathrm{h}_{2}=$ Outdoor heat transfer coefficient

\section{RESULTS AND DISCUSSIONS}

In this investigation the extreme climate \& temperature condition of India has been considered as shown in table -3 .

The influence of different parameters viz. type glazing system (single glazing, double glazing), pane-blind spacing, slat angle $\left(0^{\circ}, 90^{\circ}\right)$ and climatic conditions (Hot-Dry, Hot-Humid, Cold-Dry) was investigated.

Observations according to full factorial design are made by keeping one parameter fix and varying the rest parameters one by one. Both the simulated and experimental response values for the planned design are shown in the table 2 .

4.1 Comparison of experimental and simulated $U$ Values

The experimental U-Values for single glazing system the U-Values varies from 1.86 to $4.23 \mathrm{~W} / \mathrm{m}^{2} \mathrm{~K}$ where as in the case of double glazed system it varies in the range of 1.7 to $2.28 \mathrm{~W} / \mathrm{m}^{2} \mathrm{~K}$. The simulated U-Values for single glazing system varies from 2.24 to 5.15 $\mathrm{W} / \mathrm{m}^{2} \mathrm{~K}$ where as in the case of double glazed system it varies in the range of 2.18 to $2.74 \mathrm{~W} / \mathrm{m}^{2} \mathrm{~K}$. The experimental values are observed to be smaller by about $20 \%$ when compared to the simulated values. This is due to the environmental effects in which the guarded hot plate apparatus is located. The heat transfer losses tend to reduce the experimental Uvalues.

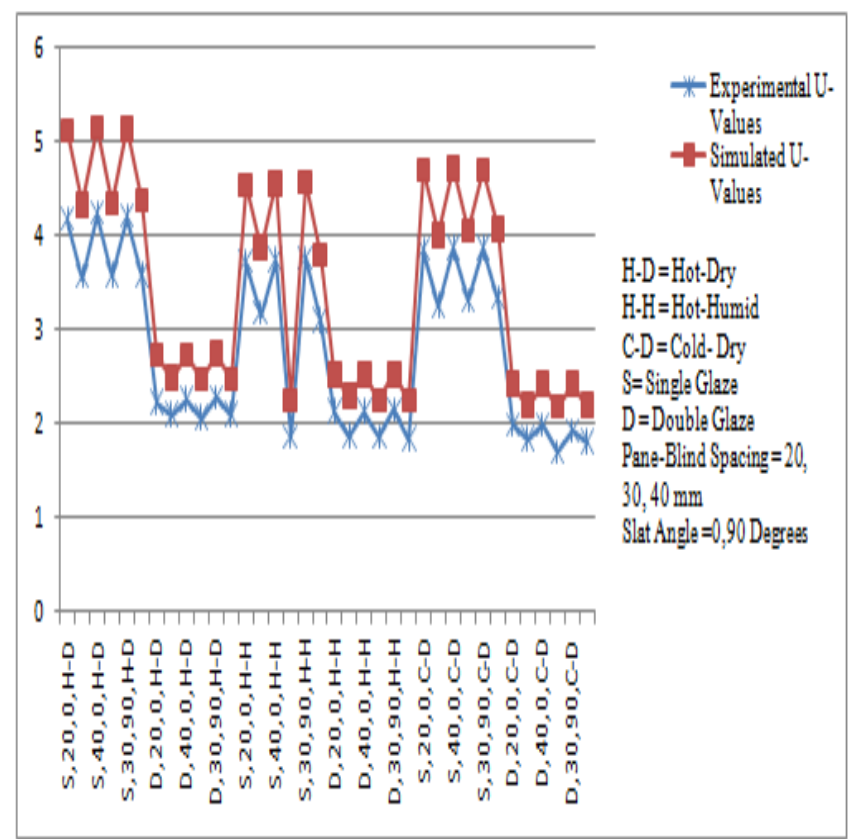

Fig-4: Graphical Representation of comparison between experimental and simulated U-Values.

\subsection{The effect of different glazing systems (single glazed and double glazed)}

By shifting from single to double glazed window, the U-Value decreases for all climatic conditions (HotDry, Hot-Humid, Cold-Dry), keeping constant the pane-blind spacing and Slat angle at different values, whose results are listed as under:

Case 1: The U-Value decreases by a minimum of $44 \%$ while using double glazing system in place of single glazing system for a pane-blind spacing of $20 \mathrm{~mm}$ and Slat angle of $0^{\circ}$.

Case2: The U-Value decreases by a minimum of $42.6 \%$ while using double glazing system in place of single glazing system for a pane-blind spacing of $20 \mathrm{~mm}$ and Slat angle of $90^{\circ}$.

Case 3: The U-Value decreases by a minimum of $44.8 \%$ while using double glazing system in place of single glazing system for a pane-blind spacing of $30 \mathrm{~mm}$ and Slat angle of $0^{\circ}$.

Case 4: The U-Value decreases by a minimum of $43.3 \%$ while using double glazing system in place of single glazing system for a pane-blind spacing of $30 \mathrm{~mm}$ and Slat angle of $90^{\circ}$. 
Case5: The U-Value decreases by a minimum of $45 \%$ while using double glazing system in place of single glazing system for a pane-blind spacing of $40 \mathrm{~mm}$ and Slat angle of $0^{\circ}$.

Case6: The U-Value decreases by a minimum of $41 \%$ while using double glazing system in place of single glazing system for a pane-blind spacing of $40 \mathrm{~mm}$ and Slat angle of $90^{\circ}$.

Thus by adding glazing system decreases the U-value by a minimum of $41 \%$ and hence improve the thermal performance of the window. This is due to the addition of insulating layer of air which reduces the heat transfer rate in addition to absorbing the radiated heat.

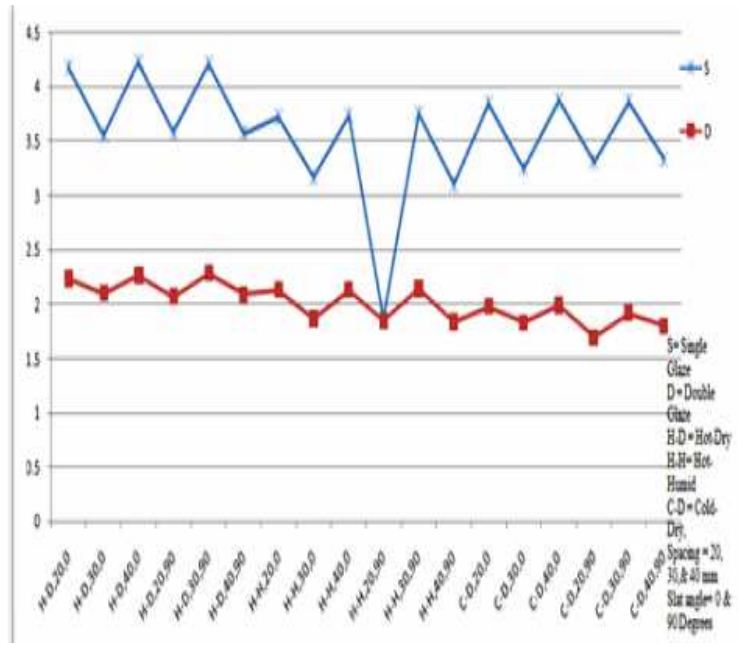

Fig-5: Graphical representation of experimental UValues of single glazing and double glazing.

\subsection{The effect of spacing}

By changing pane-blind spacing from $20 \mathrm{~mm}$ to $30 \mathrm{~mm}$ and then to $40 \mathrm{mmm}$, the U-value decreases for all climatic conditions (Hot-Dry, Hot-Humid, Cold Dry), keeping constant the type of glazing system and Slat angle at different levels, whose results are listed as under:

Case 1: The U-Value decreases by a minimum of $15 \%$ while increasing the pane-blind spacing from $20 \mathrm{~mm}$ to $30 \mathrm{~mm}$ and then to $40 \mathrm{~mm}$ for a single glazed system and a slat angle of $0^{\circ}$.

Case2: The U-Value decreases by a minimum of $7 \%$ while increasing the pane-blind spacing from
$20 \mathrm{~mm}$ to $30 \mathrm{~mm}$ and then to $40 \mathrm{~mm}$ for a double glazed system and a slat angle of $0^{\circ}$.

Case 3: The U-Value decreases by a minimum of $14 \%$ while increasing the pane-blind spacing from $20 \mathrm{~mm}$ to $30 \mathrm{~mm}$ and then to $40 \mathrm{~mm}$ for a single glazed system and a slat angle of $90^{\circ}$.

Case 4: The U-Value decreases by a minimum of $11 \%$ while increasing the pane-blind spacing from $20 \mathrm{~mm}$ to $30 \mathrm{~mm}$ and then to $40 \mathrm{~mm}$ for a double glazed system and a slat angle of $90^{\circ}$.

Thus increasing the space between the pane-blind the decreases U-Value. This may be due to the increase in convection between pane-blind which increase the heat transfer rate.

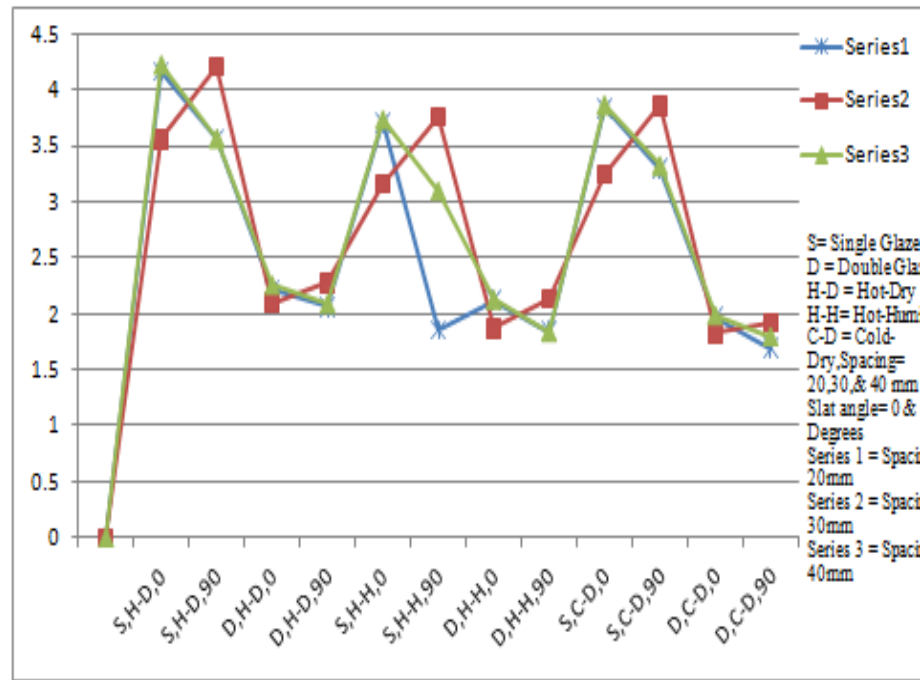

Fig-6: Graphical representation of the effect of spacing

\subsection{Effect of slat angle}

It has been observed that climatic effect has very little influence on the U-Value, neglecting this impact the U-Value is observed to decrease while shifting from $0^{\circ}$ to $90^{\circ}$ slat angle. Hence only the climate of hot-humid has been discussed as below.

Case1: The U-Value decreases by a minimum of $0.025 \%$ while increasing the slat angle from $0^{\circ}$ to $90^{\circ}$ for a single glazed system and a pane-blind spacing of $20 \mathrm{~mm}$. 
Case 2: The U-Value decreases by a minimum of $0.003 \%$ while increasing the slat angle from $0^{\circ}$ to $90^{\circ}$ for a double glazed system and a pane-blind spacing of $20 \mathrm{~mm}$.

Case 3: The U-Value decreases by a minimum of $\overline{0.02 \%}$ while increasing the slat angle from $0^{\circ}$ to $90^{\circ}$ for a single glazed system and a pane-blind spacing of $30 \mathrm{~mm}$.

Case 4: The U-Value decreases by a minimum of $0.003 \%$ while increasing the slat angle from $0^{\circ}$ to $90^{\circ}$ for a double glazed system and a pane-blind spacing of $30 \mathrm{~mm}$.

Case 5: The U-Value decreases by a minimum of $0.027 \%$ while increasing the slat angle from $0^{\circ}$ to $90^{\circ}$ for a single glazed system and a pane-blind spacing of $40 \mathrm{~mm}$.

Case 6: The U-Value decreases by a minimum of $0.003 \%$ while increasing the slat angle from $0^{\circ}$ to $90^{\circ}$ for a double glazed system and a pane-blind spacing of $40 \mathrm{~mm}$.

Thus the slat angle does not have much effect on the average convective or radiative heat flux from the glass.

The results are similar to Collins [10].

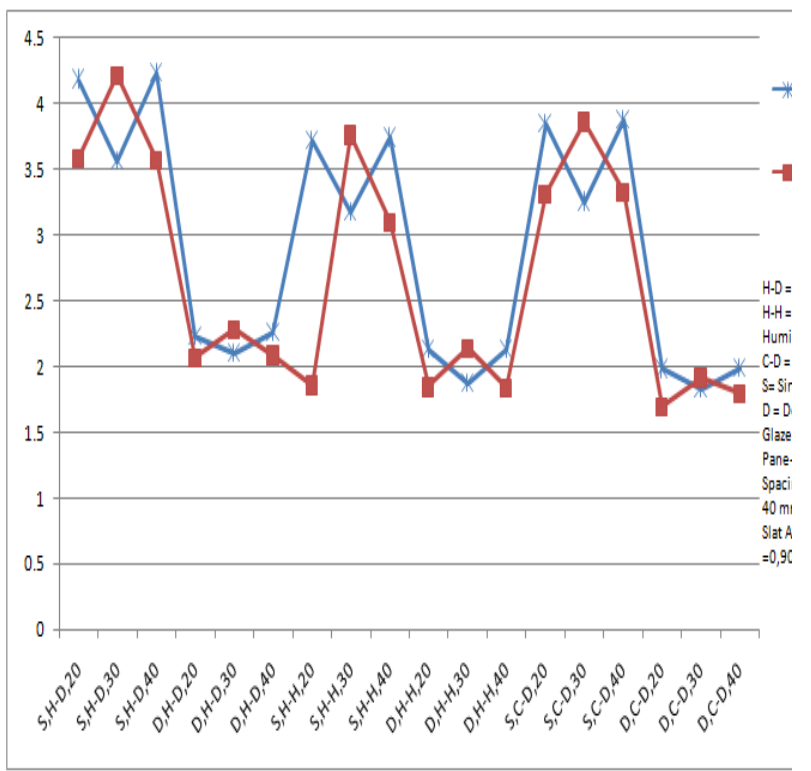

Fig-7: Graphical representation of the effect of slat angle on the U-value

\subsection{Effect of Climate}

By changing the climatic conditions from Hot-Dry to Hot-Humid and then to Cold -Dry, the U-Value decreases for all climatic conditions, keeping constant the type of glazing system and pan-blind spacing at different levels, whose results are listed as under:

Case1: The U-Value decreases by a minimum of $0.0002 \%$ while using single glazing system for a pane-blind spacing of $20 \mathrm{~mm}$ and Slat angle of $0^{\circ}$.

Case 2: The U-Value decreases by a minimum of $0.0016 \%$ while using single glazing system for a pane-blind spacing of $30 \mathrm{~mm}$ and Slat angle of $0^{\circ}$.

Case 3: The U-Value decreases by a minimum of $0.0002 \%$ while using single glazing system for a pane-blind spacing of $40 \mathrm{~mm}$ and Slat angle of $0^{\circ}$.

Case 4: The U-Value decreases by a minimum of $0.0007 \%$ while using single glazing system for a pane-blind spacing of $20 \mathrm{~mm}$ and Slat angle of $90^{\circ}$

Case 5: The U-Value decreases by a minimum of 0.1 $\%$ while using single glazing system for a pane-blind spacing of $30 \mathrm{~mm}$ and Slat angle of $90^{\circ}$.

Case 6: The U-Value decreases by a minimum of $0.0013 \%$ while using single glazing system for a pane-blind spacing of $40 \mathrm{~mm}$ and Slat angle of $90^{\circ}$. Case 7: The U-Value decreases by a minimum of $0.0068 \%$ while using double glazing system for a pane-blind spacing of $20 \mathrm{~mm}$ and Slat angle of $0^{\circ}$.

Case 8: The U-Value decreases by a minimum of $0.0011 \%$ while using double glazing system for a pane-blind spacing of $30 \mathrm{~mm}$ and Slat angle of $0^{\circ}$.

Case 9: The U-Value decreases by a minimum of $0.0185 \%$ while using double glazing system for a pane-blind spacing of $40 \mathrm{~mm}$ and Slat angle of $0^{\circ}$.

Case 10: The U-Value decreases by a minimum of $0.018 \%$ while using double glazing system for a pane-blind spacing of $20 \mathrm{~mm}$ and Slat angle of $90^{\circ}$.

Case 11: The U-Value decreases by a minimum of $0.0043 \%$ while using double glazing system for a pane-blind spacing of $30 \mathrm{~mm}$ and Slat angle of $90^{\circ}$. 
Case 12: The U-Value decreases by a minimum of $0.0009 \%$ while using double glazing system for a pane-blind spacing of $40 \mathrm{~mm}$ and Slat angle of $90^{\circ}$.

Thus by changing the climatic condtions i.e from Hot-Dry to Hot-Humid and then Cold-Dry the Uvalue decreases by a less than $1 \%$. Hence the climatic condition does not have much effect on the U-Value.

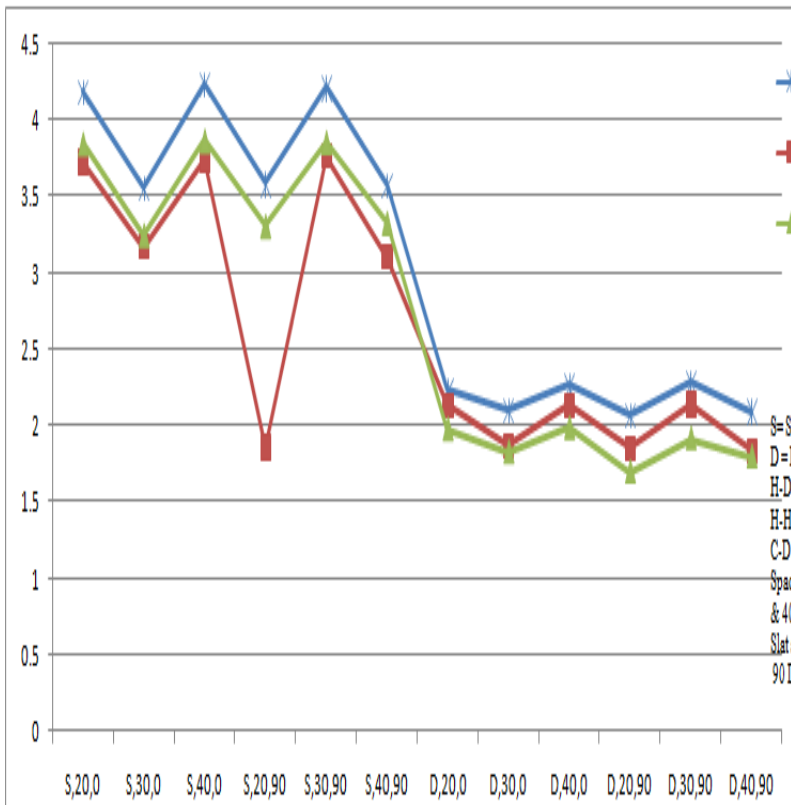

\section{REFERENCES}

[1] B.A. Lomanowski and J.L. Wright, Heat transfer analysis of windows with venetian blinds: a comparative study, 2nd Canadian Solar Buildings Conference Calgary, 2007

[2] Xian Devi Fang, A study of U- Factor of the window with a high- reflectivity venetian blind: solar energy, Vol. - 68.

No 2 pp 207-14, 2000

[3] Windows and Daylighting Group, "WINDOW 6 and THERM 6 Technical Documentation," Lawrence Berkeley National Laboratory, 3 September 2013. [Online]. Available:
Fig-8: Graphical representation of the effect of climatic conditions on the U-value

\section{CONCLUSION}

As lower U-value of the glazing system is desired, the following conclusions are made from the present work:

1. Pane-blind spacing has significant impact on the Uvalue.

2. Slat angle does not have much effect on the average convective or radiative heat flux from the glass.

3. For Hot-Dry months in Chandigarh, double glazed windows with a pane-blind spacing of $20 \mathrm{~mm}$ and a slat angle of $90^{\circ}$ is better as its $\mathrm{U}-\mathrm{V}$ alue is $2.07 \mathrm{~W} / \mathrm{m}^{2} \mathrm{~K}$.

4. For Hot-Humid months in Chandigarh, double glazed windows with a pane-blind spacing of $40 \mathrm{~mm}$ and a slat angle of $90^{\circ}$ is better as its U-Value is $1.84 \mathrm{~W} / \mathrm{m}^{2} \mathrm{~K}$. 5. For Cold-Dry months in Chandigarh, double glazed windows with a pane-blind spacing of $20 \mathrm{~mm}$ and a slat angle of $90^{\circ}$ is better as its U-Value is $1.7 \mathrm{~W} / \mathrm{m}^{2} \mathrm{~K}$.

6 . Keeping in view the greater duration of hotter months in Chandigarh, greater cooling load and also the economic feasibility the authors recommend the use of double glazed windows with a pane spacing of $20 \mathrm{~mm}$ for this region.
http://windows.lbl.gov/software/window/6/TechnicalDocs.htm 1. [Accessed 8 November 2013].

[4] N. Bansal and G. Minke, Climatic zones and rural housing in India Part 1 of the Indo-German project on passive space conditioning: 1113N-Building technology; 05V-urban planning, rural planning, transport planning, countryside conservation; 08N-Meterology, climatology, pp 288,1998

[5] Collins M.R and Harison, S.J, Calorimetric measurement of the inward flowing fraction of absorbed solar radiation in venetian blinds, ASHRARE transactions, Vol. 105(2),pp 1022-30, 1999

[6] Windows and Daylighting Group, "Windows 6.3," Lawrence Berkeley National Laboratories, 26 June 2013. Available Online: http://windows.lbl.gov/software/window/6/. [Accessed 14 Sept. 2013]

[7] http://m.accuweater.com

[8] Lake, K.L, A white paper on manufacturing and assembling on an affordable quick - to - build and sustainable 
mass housing solution for Indian cities, India Concept House, 2011

[9] J.L Wright and H.F Sullivan, Glazing system U-Value measurement using a guarded heater plate apparatus, ASHRAE Transitions, Vol. 94,pt. 2, 1988

[10] Collins, M.R, Harrison, S.J, Oosthuizen, P.H and Naylor, Sensitivity analysis of heat transfer from an irradiated window and horizontal louvered blind assembly, ASHRAE Transitions, Vol. 108 (1),pp 503-511, 2002 